\title{
The Degree of the Practice of Social Responsibility by the Principals of the Public High Schools in Jordan and its Relationship to Teachers' Organizational Commitment
}

\author{
Hatim Ratib Al-Jbour ${ }^{1} \&$ Ahmad Battah ${ }^{2}$ \\ ${ }^{1}$ Ministry of Education, Jordan \\ 2 The University of Jordan, Jordan \\ Correspondence: Hatim Ratib Al-Jbour, Ministry of Education, Jordan. E-mail: aljbourhatim@yahoo.com
}

Received: August 26, 2018

doi:10.5539/mas.v12n10p113
Accepted: September 8, 2018

Online Published: September 26, 2018

URL: https://doi.org/10.5539/mas.v12n10p113

\begin{abstract}
The current study aimed to identify the degree of the practice of social responsibility by the principals of the public high schools in Jordan and its relationship to teachers' organizational commitment. The sample of study composed of (284) principals and (765) teachers. Two research instruments were developed; the first is for social responsibility that included 4 fields in (46) items, and the second is for the organizational commitment that included 4 fields in (39) items. The validity and reliability of research instruments were verified.

The results of the study indicated that the degree of the practice of social responsibility by the principals of public high schools in Jordan was high and that the teachers' organizational commitment was high too. The results showed that there is a positive and statistically significant relationship of all fields of social responsibility and organizational commitment from the principals and teachers' points of view. There are statistically significant differences in social responsibility and organizational commitment of teachers due to the gender variable in favor of females. There are differences between the means of social responsibility attributable to the academic qualification variable in favor of Bachelor'sandDiploma. There are differences between the means of organizational commitment fields attributable to the academic qualification in favor of Bachelor's degree. There are differences between the means of social responsibility attributable to the experience year variable in favor of +10 year experience. There are no differences between the meansof organizational commitment fields attributable to the experience variable. There are statistically significant differences in social responsibility fields attributable to the job title variable in favor of school principal. There are no statistically significant differences in the organizational commitment fields attributable to the job title variable except for the fields of the responsibility for education and desire to continue at work.

The current study came up with a number of recommendations, mainly to maintain the level of the practice of social responsibility by the principals of public high schools in Jordan and to benefit from the supporters from among the community and keep them involved in decision making to developschool future plans.
\end{abstract}

Keywords: social responsibility, organizational commitment

\section{Introduction}

Education is an essential pillar in the advancement of nations and the primary element in achieving the progress and well-being of societies. Hence, the Ministry of Education seeks, through its vision and mission, to promote the concept of loyalty and belongingness in its students. This vision can only be achieved by the principals of schools, who are the leaders and supervisors in their schools. They seek, through their cooperation with the teachers, to raise the level of the educational process, improve the results of their students and achieve professional development of their teachers, so that the school can communicate effectively with the community and provide it with the necessary services.

Pedagogues agreed on the importance of the social role of the school as a social institution created by the society to serve its people and contribute to solving its problems, achieving its objectives and leading its development. In order for the school to accomplish this role, it is necessary for it to interact with the community to influence and be influenced by it and to foster its relationship with the parents who are the focus of mutual interest. The school 
should further develop mutual understanding and friendship with the community, select the best means to make the society aware of school tasks, activities, objectives, programs, and problems, and work to develop plans and appropriate solutions to serve the community (Al-Saud, 2013).

It is therefore necessary for Government bodies to support social responsibility activities, most notably the Ministry of Education, which should develop syllabuses tocontain an educational dimension and practical activities related to social responsibility, although its syllabuses already include national education that is based on how to socialize children to love the homeland and belong to it and to preserve and maintain public properties. This is part of the social responsibility of the Ministry of Education (Awad, 2010).

The community schools that seek to serve the community should have an effective educational leadership in order to guide the staff towards achieving their goals. Therefore, teachers are the mainstay for the school to carry out its social duty. This can only be achieved through their organizational commitment to their work. Here appears the interest of researchers in the subject of teachers' organizational commitment, due to its importance in the success of the work. It is a positive and desirable behavior that the educational institution, including the publichigh schools, seeks to support and develop among its staff. It generates a sense of belongingness and loyalty to the work, which is reflected positively on the schools and achieving the goals effectively. The school leadership should direct all the human and material resources to carry out its work through planning and organized coordination appropriate for the achievement of the goals with the level of the leadershipability to take advantage of the energies of the staffand reveal their potentials to reach a high level of organizational commitment (The Ministry, 2015).

The importance of organizational commitment in educational institutions, especially the schools, is reflected in organizational climate, student accomplishment and the achievement of belongingness, accomplishment and selfrealization of teachers, especially in the secondary stage, which is one of the most important stages in students' lives, in which they form their values, beliefs, interests,and attitudes. The power of organizational commitment is reflected inthe educational institution and its staff, in which the team members show their abilities and loyalty to the organization to achieve its objectives in exchange for employee satisfaction (Al-Rashidi, 2014).

The concept of organizational commitment has received the attention of a large number of educational researchers for its impact on the behavior of individuals on the one hand and the institution in which they work on the other hand. This attention began in the mid-1990s as a result of the interaction between the characteristics of the employees of the institution and the pressure of work, in addition to other organizational factors, including personal and behavioral ones (Mohamed, 2015).

Organizational commitment increases the ability and efficiency of the teacher and his contribution within the classroom, as he is the centralpivot in the educational process and has the ability to manage the classroom. The teacher's methods and activities are the most essential factors for the success of the educational process and the achievement of its goals. A committed teacher becomes psychologically connected with his school and forms positive attitudes towards his students. Accordingly, he accepts the school objectives and becomes integrated into them and thus feels integrated and engaged in work, the matter which gives him security and a sense of stability and staying longer (Qanadili, 2015).

Organizational commitment enables the teachers to acquire great experiences through on-the-job training courses, which positively reflects on the school and students in particular and enables them to build positive human relations with their colleagues, the administration and the community, especially the parents. This, in turn,forms a strong educational system, which is characterized by compatibility and harmony, thus enabling the school to compete and achieve excellence and creativity (Al-Subai'ee, 2016).

\section{Study Problems and Questions}

The excellence of educational institutions, especially the schools, depends on the excellence of their active leaders and the quality of teachers who practice the profession of education therein, as the school seeks to exercise its social role in the awareness and service of the community. Social responsibility depends on systematic planning to achieve the wishes of the staff members of the educational institution in order to contribute to the development of the community. This can only be achieved withstaff organizational commitment, which enables the leader to promote and raise the institution. The individual sees himself as an integral part of his institution in which he works, which achieves his satisfaction and career stability, in order for it to be able to perform its social role to the fullest extent. Thus, the problem of the current study is represented in answering the following questions:

1. What is the degree of the practice of social responsibility by the principals of public high schools in Jordan from the principals and teachers' points of view? 
2. What is the degree of teachers' organizational commitment in public high schools in Jordan from the teachers and principals' points of view

\subsection{Study objectives}

The current study aimed to:

1. Realize the degree of the practice of social responsibility by the principals of Public high schools in Jordan from their point of view and its relationship to teachers' organizational commitment.

2. Realize the degree of teachers' organizational commitment in Public high schools in Jordan from the principals' point of view.

\subsection{Study Importance}

The importance of the current study lies in the global interest in the concept of social responsibility and its positive impact on the performance of the educational institution, especially the schools, in addition to the need of principals of schools to encourage and activate social responsibility initiatives. It is hoped that the following parties will benefit from the results of this study:

- $\quad$ Educational policy-makers in the Ministry of Education by understanding the roles of principals of schools in practicing social responsibility, which will help them to develop their performance to serve the community.

- $\quad$ Researchers, Pedagogues and those interested in the field of educational management.

- $\quad$ It is hoped that the current study will provide recommendations to identify the obstacles facing the schools in exercising the concept of social responsibility and the means to develop it for the sake of community service.

\subsection{Study Terminology}

Social Responsibility: It is the translation of the English term "Social Responsibility".There have been several attempts to define this term, including the definition by the World Business Council for Sustainable Development (WBCSD), which defines "Social Responsibility" as "the continued commitment by business organizations to act ethically, contribute to the achievement of economic development and work to improve the quality of living conditions of the workforce and their families as well as the community and society as a whole" (WBCSD). The term "Social Responsibility" was also defined by Al-Sayed (2010) as "the harmony of educational institutions in their works and activities with the expectations of the society and their response to its legal, ethical, value and environmental requirements".

The term "Social Responsibility" is procedurally defined by the two current researchers as "the set of services and facilities provided by principals of schools and their staff to serve the community, provide it with the necessary support, understand its needs and contribute to solving its problems within the values and legal and ethical frameworks that govern this society with a view to achieve the welfare, development and social stability of its members". It was measured by the study instruments developed by the twocurrent researchers for this purpose.

Organizational Commitment: This term was defined by Al-Kayed (1999) as: "the willingness of an individual to exert a high degree of effort in favor of the organization in which he works, with the real desire to continue within the organization and accept its goals and values. The term "Organizational Commitment" was also defined by McShane\&Glinow (2005) as "the degree to which an employee is immersed in his work and the extent of his loyalty to the organization in which he works, as he connects his goals to its goals, ensures its survival and continuity, becomes integrated into working in it and is linked to its values.

The term "Organizational Commitment" is procedurally defined by the two current researchers as "the inner sense of commitment to the work, the teachers' conviction of the school goals that drive them to adhere to it, their desire for its success and their sense of loyalty and belongingness to it. It was measured by the study instruments developed by the twocurrent researchers for this purpose.

\subsection{Study limitations}

- Human limitation: (1161) male and female principals of public high schools and (16915) male and female teachers.

Time limitation: The school year 2017/2018.

Place limitations: (1161) public high schools in Jordan. 


\section{Review of Literature}

\subsection{Literature on Social Responsibility}

Ahmed (2017) conducted a study to identify the role of the school administration in motivating the community towards a participatory relationship with the public high schools in Irbid governorate. The researcher used a questionnaire tool consisting of (38) items divided into four fields (local education, participation with public services, activities and participations in scientific researches and studies and participation with private sector). The sample of the study consisted of (720) male and female teachers. The results of the study showed that the school administration plays an important role in stimulating the community in order to build a positive participatory relationship. The results were medium and found statistically significant differences attributable to the gender variable in all fields in favor of females, while there were no differences attributable to experience and academic qualification variables for all fields, except for the educational field, where the differences were in favor of holders of Bachelor's degree.

A study by Shallsh (2017) aimed to identify the degree of application of the concept of community school in Salfit public schools from the point of view of male and female principals and its obstacles. The study used the instrument of survey, which consisted of (45) items and included three fields (partnership with the community, partnership with the parents, and the obstacles). The results of the study showed a great degree of application of the concept of the community school by the principals of schools, which was highest in the field of partnership with the parents $(85 \%)$ and lowest in the field of the obstacles $(71 \%)$, and that there were no statistically significant differences attributable to the study variables.

Vorhis and Sheldon (2014) conducted a study to reveal the role of principals in American schools in the development of community partnership programs. The study used questionnaire as a tool. The study consisted of (520) male and female principals of public schools. Results showed that there was a positive relationship between competencies of principals and their ability to develop programs for the development of partnership with the community, in addition to the availability of financial support for them to properly plan for the development of the partnership programs.

A study byPreston (2011) aimed to identify the effect of social participation and educational boards in the development of the concept of community schools. The study used questionnaire as an instrument. The sample composed of (35) social activists. Results showed that there was a clear perception of the support provided by academic activists to promote the concept of the community school and that most of the activists prefer to create partnerships between the school and the community in order to provide high-quality education.

\subsection{Literature on Organizational Commitment}

Ali (2017) conducted a study to reveal the relationship between the practice of leadership by the heads and supervisors of the academic departments in Tabuk University and the degree of organizational commitment among faculty members. The researcher used questionnaire as an instrument. The sample consisted of (131) staff members. The results showed that the degree of the practice of leadership by the department heads and supervisors was great. There were statistically significant differences attributable to the gender variable for the leadership field in favor if males. There were no differences at the level of $(0.01)$ in favor of humanities specialty. There were no differences attributable to the position and academic degree variables for the serving leadership field. However, there were differences at the level of (0.05) in favor of associate professor and professor. In addition, there was a positive correlation between the degree of the practice of serving leadership by the heads and supervisors of academic departments in all its dimensions and the organizational commitment of faculty members.

Attia (2016) conducted a study aimed to identifythe degree of organizational commitment among faculty members in Baha University and its effect on their performance level from their point of view. The researcher used the questionnaire as a tool. The study sample consisted of (98) faculty members who were randomizedat $11.3 \%$ of study population. The results showed that the degree of organizational commitment among faculty members was significantly high in the following descending order: organizational commitment, emotional commitment and continued commitment. There were no statistically significant differences attributable to the variables of nationality, gender, assignment of administrative work, academic degree and years of experience. There were statistically significant differences attributableto the variable of college location in favor of faculty members in the governorates. The results also showed that the organizational commitment has an incorporeal impact on the level of job performance.

Parker, Giuffetle and Flessa (2011) conducted a study on the organizational climate of community schools in Ontario, Canada and ways to overcome adverse environmental conditions. The study used interviews through field 
visits as a tool. The sample consisted of (11) primary schools that apply the concept of community school. The researcher collected the data and analyzed it using content analysis. Results showed that the prevailing organizational climate in these schools was based on schoolmate and cooperation between teachers and school administrators, in addition to the creation of partnerships with local community.

Moore \& Moore (2014) conducted a study to reveal the impact of the ethical climate on the relationship between organizational commitment and job satisfaction among faculty members in higher education institutions in North Carolina, Oklahoma, Tennessee, and Texas. The questionnaire was used as a study instruments. The sample consisted on (594) faculty members. Resultsshowed that there were differences in the level of commitment and job satisfaction among faculty members who work on a full-time basis with the ethical climate of those institutions. There were statistically significant differences in the responses of the sample members at the level of organizational commitment attributable to the gender variable in favor of females.The study also showed a positive correlation between the degree of organizational commitment among faculty members and their job satisfaction level.

A study by Celep (2001) aimed to identify the level of teachers' organizational commitment in educational institutions. The study used questionnaire as an instrument to measure organizational commitment, which consisted of (28) items divided into 4 dimensions (commitment to school, commitment to education profession, commitment to educational work and commitment to teamwork). The sample of study consisted of (302) teachers of high schools in Zonguldak, Turkey. The researcher used Lautusters and Munday scale (1997) and Moord scale for the commitment to work. Results showed that there was a relationship between organizational commitment and teachers' pride of being part of their school and working within a team, and that the teachers were very committed and respected the profession of teaching. There was an intimate relationship between co-workers and a correlation between the dimensions of the organizational commitment in all its fields.

\subsection{Comment on Previous Literature and the Position of the Current Study}

Through the review of the previous studies relevant to the current study and understanding their theory and methodology, it is indicated that they sought to demonstrate the importance of the concept of social responsibility in educational institutions, whether universities or schools. Thus, their results differed and varied in content.

The previous literature varied in sample and study population. Ahmed's study (2017) identified the role of school administration in motivating the community towards a participatory relationship with government schools. The current study is to some extent similar to Talafha's study (2017) in knowing the role of administration in activating partnership between the school and the community from the point of view of male and female teachers. Most of the studies indicated the role of school administration in activating partnership and community service with various methodologies that varied between descriptive and experimental methods, and attempted to deal with the concept of teachers' organizational commitment. For example, Attia's study (2016) identified the degree of organizational commitment of faculty members in Baha University and its effect on their job performance. In addition, most of the foreign studies dealt differently with the concept of organizational commitment. The two current researchers benefited from previous literature in preparing the theoretical framework of the current study and enriching it with a number of ideas related to the concept of social responsibility among principals of schools and teachers' organizational commitment in order to construct the current study instrument.

The current study is distinguished from the previous literature in terms of study population represented by principals and teachers of Public high schools in Jordan. In addition, it is the first study that aims to realize the role of the principals of Public high schools in Jordan in activating social responsibility and its relationship to teachers' organizational commitment.

\section{Methodology and Procedures}

\subsection{Study Methodology}

The two researchers adopted the descriptive correlative approach in this study by collecting data and constructing the instrument that was distributed to the study sample by referring to the theoretical literature and statistical analysis of data in order to answer study questions.

\subsection{Study Population}

The study population consisted of (1161) male and female principals, and (16915) male and female teachers of (18076) public high schools in Jordan according to the statistics of the Ministry of Education for the school year 2016/2018.

\subsection{Study Sample}


The sample was selected by the stratified cluster method from the Public high schools in Jordan (north, center and south), in the north (Irbid and Mafraq governorates), in the center (Amman and Madaba) and in the south (Karak and Tafila), with total of (1049) members, as illustrated in the following table:

Table 1. The distribution of study population members according to the variables of (gender, academic qualification, experience and job title) in the Ministry of Education in Jordan

\begin{tabular}{llll}
\hline & Categories & Frequency & Ratio \\
\hline \multirow{2}{*}{ Job title } & Principal & 284 & 27.1 \\
& Teacher & 765 & 72.9 \\
\hline \multirow{2}{*}{ Gender } & Male & 618 & 58.9 \\
& Female & 431 & 41.1 \\
\hline \multirow{3}{*}{ Academic qualification } & Bachelor's & 546 & 52.0 \\
& Bachelor's + Diploma & 317 & 30.2 \\
\hline \multirow{2}{*}{ Experience } & Post-graduate studies & 186 & 17.7 \\
& Less than 5 years & 114 & 10.9 \\
\hline Total & $5-10$ years & 258 & 24.6 \\
\hline
\end{tabular}

\subsection{Study Instruments}

In order to achieve the study objectives, the two researchers developed two instruments for gathering data by referring to educational literature and previous studies related to the subject of the current study. The two questionnaires in their final forms consisted of 4 fields of social responsibility in (46) items and 4 fields of organizational commitment in (39) items.

\subsection{Validity and Reliability of Study Instruments}

In order to verify the validity of the instruments, the current study adopted the method of "content validity) by presenting the two instruments to a group of experts and specialists in the field of educational administration and statistics in the universities of Jordan by presenting them to 10 arbitrators to determine their degree of validity and relevance to the subject of the current study as well as the suitability of eachitem for the dimension it measures.

In order to verify the reliability of the two instruments, the researchers calculated the internal consistency coefficient (Cronbach's alpha). Tables (2) and (3) illustrate the values of the coefficients of Cronbach's alpha for the consistency of the items of the two instruments with the fields of social responsibility and organizational commitment.

Table 2. The reliability of the fields of social responsibility among principals of schools using Cronbach's alpha method

\begin{tabular}{|c|c|c|c|}
\hline \multirow[b]{2}{*}{ Field } & \multirow[b]{2}{*}{$\begin{array}{l}\text { No. of items } \\
\text { for each field }\end{array}$} & \multicolumn{2}{|c|}{ Cronbach's alpha value } \\
\hline & & $\begin{array}{l}\text { From the } \\
\text { pilot sample } \\
\mathbf{N}=\mathbf{3 0}\end{array}$ & $\begin{array}{l}\text { From the } \\
\text { main sample } \\
\mathrm{N}=1049\end{array}$ \\
\hline Partnership with community & 16 & 0.929 & 0.932 \\
\hline Relationship with parents & 13 & 0.928 & 0.937 \\
\hline Education & 9 & 0.943 & 0.930 \\
\hline Environmental field & 8 & 0.952 & 0.939 \\
\hline Social responsibility & 46 & 0.976 & 0.975 \\
\hline
\end{tabular}

Table (2) illustrates the results of the reliability of the fields of social responsibility questionnaire using Cronbach's alpha method measured in two cases; the first is through pilot sample in an initial stage and the second is through the data of the complete study sample. Results indicate that the fields have a high degree of internal consistency in the two cases of assessment, where

the reliability value of the degree of the practice of social responsibility by the principals of Public high schools in Jordan as a whole was (0.976) of the pilot sample and (0.975) of the main sample.It is noted that the values of the reliability of the sub-fields were also very high in the case of reliability assessment (in both pilot and main sample), 
where the least value of this reliability was achieved in the field of the relationship with parents, amounting to (0.928) in case of assessment through the pilot sample. This value is considered high since the largest value that may be reached by reliability is 1 . Hence we deduct the reliability of the social responsibility questionnaire and its suitability for use and gathering of the data related to the subject of this study.

Table 3. The reliability of the fields of organizational commitment using Cronbach's alpha method

\begin{tabular}{cccc}
\hline Field & $\begin{array}{c}\text { No. of items for } \\
\text { each field }\end{array}$ & $\begin{array}{c}\text { From the pilot } \\
\text { sample } \\
\mathbf{N}=\mathbf{3 0}\end{array}$ & $\begin{array}{c}\text { From the main } \\
\text { sample } \\
\mathbf{N}=\mathbf{1 0 4 9}\end{array}$ \\
\hline Belongingness to work & 8 & 0.893 & 0.932 \\
Responsibility for education & 15 & 0.947 & 0.959 \\
Desire to continue at work & 8 & 0.855 & 0.897 \\
Professional belongingness & 8 & 0.914 & 0.928 \\
Organizational commitment & 39 & 0.959 & 0.972 \\
\hline
\end{tabular}

Table (3) illustrates the results of the reliability of the fields of organizational commitment questionnaire using Cronbach's alpha method measured in two cases; the first is through pilot sample in an initial stage and the second is through the data of the complete study sample. Results indicate that the fields have a high degree of internal consistency in the two cases of assessment, where the reliability value of the degree of organizational commitment by Public high school teachers in Jordan as a whole was (0.959) of the pilot sample and (0.972) of the main sample. It is noted that the values of the reliability of the sub-fields were also very high in the case of reliability assessment (in both pilot and main sample) separately, where the least value of this reliability was achieved in the field of the desire to continue at work, amounting to (0.855) in case of assessment through the pilot sample. This value is considered high since the largest value that may be reached by reliability is 1 . Hence we deduct the reliability of the organizational commitment questionnaire and its suitability for use and gathering of the data related to the subject of this study.

\subsection{Study Variables}

This study includes the following variables:

Independent variables: They include gender (male, female), academic qualification (Bachelor's, Bachelor's and Diploma, post-graduate studies), experience (less than 5 years, 5-10 years, more than 10 years) and job title (principal, teacher).

Dependent variable: Social responsibility and organizational commitment.

\section{Statistical treatment}

Means, standard deviations and ranks were used to answer questions 1 and 2.

\section{Study results}

\subsection{Results Related to Question 1: What is the Degree of the Practice of Social Responsibility by the Principals of} Public High Schools in Jordan from the Principals and Teachers' Points of View?

To answer this question, the researchers calculated the means, standard deviations and rank of the degree of the practice of social responsibility by the principals of Public high schools in Jordan from the point of views of the principals and teachers, which are illustrated in Table (4).

Table 4. Means and standard deviations of the fields of the degree of the practice of social responsibility by the principals of Public high schools in Jordan from the point of view of the principals and teachers in descending order

\begin{tabular}{ccccccc}
\hline No. & Field & Means & $\begin{array}{c}\text { Standard } \\
\text { deviation }\end{array}$ & $\begin{array}{c}\text { Relative } \\
\text { importance }\end{array}$ & Level & order \\
\hline 3 & Education & 3.84 & 0.88 & 76.80 & High & 1 \\
2 & Relationship with parents & 3.82 & 0.84 & 76.40 & High & 2 \\
\hline
\end{tabular}




\begin{tabular}{rrrrrrr}
\hline 4 & Environmental field & 3.71 & 0.96 & 74.20 & High & 3 \\
1 & Partnership with & 3.48 & 0.85 & 69.60 & Medium & 4 \\
& community & 3.71 & 0.80 & 74.20 & High \\
\hline
\end{tabular}

It is noted from Table (4) that the fields of the degree of the practice of social responsibility by the principals of Public high schools in Jordan were high. The means was (3.71) with relative importance of (74.20). The level of fields was between medium and high, where the means varied between $(3.84-3.48)$. The field of education was in the first rank with a means of (3.84) and relative importance of (76.80). The field of the relationship with parents was in the second rank with a means of (3.82) and relative importance of (76.40). The field of environment was in the third rank with a means of (3.71). The field of partnership with community was in the fourth rank with a means of (3.48) and relative importance of (69.60).

The researchers analyzed the fields of the degree of the practice of social responsibility by the principals of Public high schools in Jordan according to its items as follows:

\section{First: The field of partnership with community}

The researchers calculated the means and standard deviations of the field of partnership with community as illustrated in Table (5).

Table 5. Means and standard deviations of the items of partnership with community in a descending order

\begin{tabular}{|c|c|c|c|c|c|c|}
\hline No. & Field & Means & $\begin{array}{l}\text { Standard } \\
\text { deviation }\end{array}$ & $\begin{array}{l}\text { Relative } \\
\text { importance }\end{array}$ & Level & order \\
\hline 1 & The school respects the culture of the community & 4.36 & 0.77 & 87.20 & High & 1 \\
\hline 3 & $\begin{array}{l}\text { The school cooperates with the Ministry of Health in the provision of } \\
\text { Healthcare }\end{array}$ & 3.94 & 1.04 & 78.80 & High & 2 \\
\hline 11 & The school values its relationships with the community & 3.79 & 1.07 & 75.80 & High & 3 \\
\hline 8 & The school organizes awareness lectures & 3.67 & 1.21 & 73.40 & Medium & 4 \\
\hline 12 & The school informs the community about its vision and goals & 3.67 & 1.12 & 73.40 & Medium & 4 \\
\hline 14 & The school honors community members in its social occasions & 3.62 & 1.20 & 72.40 & Medium & 6 \\
\hline 2 & The school engages the community in the preparation of its plan & 3.59 & 1.12 & 71.80 & Medium & 7 \\
\hline 7 & The school holds educational lectures & 3.59 & 1.23 & 71.80 & Medium & 7 \\
\hline 16 & The school invites parents to participate in recreational activities & 3.57 & 1.24 & 71.40 & Medium & 9 \\
\hline 9 & The school organizes an open day for parent visits & 3.55 & 1.27 & 71.00 & Medium & 10 \\
\hline 13 & $\begin{array}{l}\text { The school benefits from the financial support provided by the } \\
\text { community members }\end{array}$ & 3.45 & 1.26 & 69.00 & Medium & 11 \\
\hline 15 & The school publishes leaflets about its activities & 3.43 & 1.24 & 68.60 & Medium & 12 \\
\hline 10 & $\begin{array}{l}\text { The school organizes visits to the neighboring professional and } \\
\text { industrial institutions }\end{array}$ & 3.29 & 1.26 & 65.80 & Medium & 13 \\
\hline 4 & The school has a free medical day & 2.96 & 1.40 & 59.20 & Medium & 14 \\
\hline 6 & $\begin{array}{l}\text { The school organizes educations workshops for the community } \\
\text { members }\end{array}$ & 2.92 & 1.36 & 58.40 & Medium & 15 \\
\hline 5 & The school provides literacy programs & 2.26 & 1.34 & 45.20 & Low & 16 \\
\hline \multicolumn{2}{|c|}{ Partnership with local community } & 3.48 & 0.85 & 69.60 & Medium & \\
\hline
\end{tabular}

It is noted from Table (5) that the level of the field of partnership with community was medium. The means was (3.48) with relative importance of (69.60). The level of items of the field was between low and high, where the means varied between $(4.36-2.26)$. The item of "the school respects the culture of the community" was in the first rank with a means of (4.36) and relative importance of (87.20). The item of "the school provides literacy programs" was in the last rank with a means of (2.26) and relative importance of (45.20).

This may be attributed to the fact that each community has its own customs, traditions and culture, and it is the obligation of individuals to respect those customs, which makes them respect the school and take care not to depart from those customs, the matter which enhances communication and achieves the required partnership.

With regard to the item that got the least means, namely "the school provides literacy programs", this may be 
attributed to the fact that the schools do not have sufficient programs prepared for this category and do not put it within its plan, in addition to the unavailability of qualified and specialized staff for such programs. Accordingly, schools need to be interested in this matter and give it greater attention as it enhances partnership with the community. The school may achieve this through the announcement of awards and incentives in cooperation with other society institutions for those who join such programs, which in turn leads to the formation of positive attitudes towards education and its importance in society progress and the improvement of economic level of its members to achieve the desired social welfare.

\section{Second: The field of the relationship with parents}

The researchers calculated the means and standard deviations of the field of the relationship with parents as illustrated in Table (6).

Table 6. Means and standard deviations of the items of relationship with parents in a descending order

\begin{tabular}{|c|c|c|c|c|c|c|}
\hline No. & Field & Means & $\begin{array}{l}\text { Standard } \\
\text { deviation }\end{array}$ & $\begin{array}{l}\text { Relative } \\
\text { importance }\end{array}$ & Level & order \\
\hline 5 & $\begin{array}{l}\text { The school interacts seriously with the questions and consultations of } \\
\text { parents }\end{array}$ & 4.06 & 0.98 & 81.20 & High & 1 \\
\hline 1 & The school activates parent-teacher assembly & 4.01 & 1.04 & 80.20 & High & 2 \\
\hline 4 & The school documents parent visits in a special record & 4.00 & 1.09 & 80.00 & High & 3 \\
\hline 3 & $\begin{array}{l}\text { The school provides parents with means of communication to follow- } \\
\text { up their children }\end{array}$ & 3.95 & 1.08 & 79.00 & High & 4 \\
\hline 12 & The school honors outstanding students in the presence of their parents & 3.94 & 1.07 & 78.80 & High & 5 \\
\hline 13 & The school invites parents to participate in school celebrations & 3.93 & 1.08 & 78.60 & High & 6 \\
\hline 11 & $\begin{array}{l}\text { The school sends monthly reports to the parents on the achievement } \\
\text { level of the students }\end{array}$ & 3.85 & 1.08 & 77.00 & High & 7 \\
\hline 6 & The school allocates time for parent visits & 3.82 & 1.13 & 76.40 & High & 8 \\
\hline 7 & The school holds regular meetings with the parents & 3.79 & 1.10 & 75.80 & High & 9 \\
\hline 8 & The school motivates parents to participate in its activities & 3.73 & 1.15 & 74.60 & High & 10 \\
\hline 9 & $\begin{array}{l}\text { The school enables parents to follow-up the results of their children } \\
\text { via OpenEMIS system }\end{array}$ & 3.66 & 1.17 & 73.20 & Medium & 11 \\
\hline 10 & $\begin{array}{l}\text { The school activates parent participation in the implementation of } \\
\text { school development plan }\end{array}$ & 3.57 & 1.19 & 71.40 & Medium & 12 \\
\hline 2 & $\begin{array}{l}\text { The school engages parents to create a fund to support the needy } \\
\text { students }\end{array}$ & 3.32 & 1.31 & 66.40 & Medium & 13 \\
\hline \multicolumn{2}{|c|}{ Relationship with parents } & 3.82 & 0.84 & 76.40 & High & \\
\hline
\end{tabular}

It is noted from Table (6) that the level of the field of the relationship with parents was high. The means was (3.82) with relative importance of (76.40). The level of items of the field was between low and high, where the means varied between $(4.06-3.32)$. The item of "the school interacts seriously with the questions and consultations of parents" was in the first rank with a means of (4.06) and relative importance of (81.20). The item of "the school engages parents to create a fund to support the needy students" was in the last rank with a means of (3.32) and relative importance of (66.40).

This may be attributed to the seriousness of parents to follow-up their children and their achievement throughout the school year, as well as the keenness of schools to inform parents about the level of their children, which will facilitate the communication process and activate the relationship between the parents and the schools in order to achieve the principle of partnership to reach the desired goals.

With regard to the item that got the least means (3.32), namely "the school engages parents to create a fund to support the needy students", this may be attributed to the lack of material resources available in schools, in addition to the absence of this idea and the degree of its importance in parent communication with the school for the principals, given their large daily burdens. In addition, sometimes there is a shame to accept the idea of support for the needy student who finds himself equal to the others and has no need. This is the role of leaders to find the appropriate way to give them what they need privately to avoid embarrassment. 


\section{Third: The field of education}

The researchers calculated the means and standard deviations of the field of the relationship with parents as illustrated in Table (7).

Table 7. Means and standard deviations of the items of education in a descending order

\begin{tabular}{|c|c|c|c|c|c|c|}
\hline No. & Field & Means & $\begin{array}{l}\text { Standard } \\
\text { deviation }\end{array}$ & $\begin{array}{l}\text { Relative } \\
\text { importance }\end{array}$ & Level & order \\
\hline 1 & The school provides a safe environment for education & 4.18 & 0.94 & 83.60 & High & 1 \\
\hline 4 & The school is keen to solve the problems of students & 4.12 & 1.01 & 82.40 & High & 2 \\
\hline 9 & The school activates student parliamentary councils & 3.94 & 1.09 & 78.80 & High & 3 \\
\hline 2 & $\begin{array}{l}\text { The school provides electronic services for the improvement of } \\
\text { education }\end{array}$ & 3.84 & 1.08 & 76.80 & High & 4 \\
\hline 7 & $\begin{array}{l}\text { The school evaluates results of students to benefit from them in the } \\
\text { improvement process }\end{array}$ & 3.82 & 1.06 & 76.40 & High & 5 \\
\hline 3 & The school provides meeting halls & 3.71 & 1.20 & 74.20 & High & 6 \\
\hline 6 & The school has an appropriate database & 3.70 & 1.15 & 74.00 & High & 7 \\
\hline 8 & $\begin{array}{l}\text { The school is keen to benefit from student participation in the } \\
\text { activation of the development plan }\end{array}$ & 3.67 & 1.13 & 73.40 & Medium & 8 \\
\hline 5 & $\begin{array}{l}\text { The school provides recent references in its library to serve the } \\
\text { education process }\end{array}$ & 3.57 & 1.19 & 71.40 & Medium & 9 \\
\hline \multicolumn{2}{|c|}{ Education } & 3.84 & 0.88 & 76.80 & High & \\
\hline
\end{tabular}

It is noted from Table (7) that the level of the field of education was high. The means was (3.84) with relative importance of (76.80). The level of items of the field was between medium and high, where the means varied between $(4.18-3.57)$. The item of "the school a safe environment for education" was in the first rank with a means of (4.06) and relative importance of (83.60). The item of "the school provides recent references in its library to serve the educational process" was in the last rank with a means of (3.57) and relative importance of (71.40).

This result may be attributed to the fact that the schools focus on the concept of a safe school environment for education and learning away from violence and keeping pace with the latest developments in the world and the rapid advances in technology. It is also interested in providing the safe school environment that helps the education process, as the Ministry seeks in its plan to achieve a safe school environment. In addition, teachers are interested in the teaching process, which is a sacred profession, and see the students as their children, and thus seek to provide them with the best education.

With regard to the item that got the least means, namely "the school provides recent references in its library to serve the educational process", this may be attributed to the lack of material resources in schools, in addition to the lack of interest of the community in the importance of libraries and their role in educating the community. Hence, it is necessary to spread the culture of learning outside the walls of the school and open the library doors for everyone to reach a conscious and educated society.

Fourth: The field of environment

The researchers calculated the means and standard deviations of the field of environment as illustrated in Table (8).

Table 8. Means and standard deviations of the items of environment in a descending order

\begin{tabular}{|c|c|c|c|c|c|c|}
\hline No. & Field & Means & $\begin{array}{l}\text { Standard } \\
\text { deviation }\end{array}$ & $\begin{array}{l}\text { Relative } \\
\text { importance }\end{array}$ & Level & order \\
\hline 1 & The school ensures that its facilities are environmentally friendly & 4.03 & 1.03 & 80.60 & High & 1 \\
\hline 5 & The school participates in the cleaning campaigns & 3.89 & 1.11 & 77.80 & High & 2 \\
\hline 2 & $\begin{array}{l}\text { The school seeks to provide environmental education services to the } \\
\text { community }\end{array}$ & 3.78 & 1.11 & 75.60 & High & 3 \\
\hline 4 & $\begin{array}{l}\text { The school provides an environment conductive to attracting members } \\
\text { of the community }\end{array}$ & 3.69 & 1.09 & 73.80 & High & 4 \\
\hline
\end{tabular}




\begin{tabular}{|c|c|c|c|c|c|c|}
\hline 8 & $\begin{array}{l}\text { The school participates in voluntary activities organized by the } \\
\text { community to take care of the environment }\end{array}$ & 3.68 & 1.16 & 73.60 & High & 5 \\
\hline 7 & $\begin{array}{l}\text { The school enhances the culture of rationalization of environmental } \\
\text { resources }\end{array}$ & 3.64 & 1.15 & 72.80 & Medium & 6 \\
\hline 3 & $\begin{array}{l}\text { The school publishes awareness leaflets to avoid damaging the } \\
\text { environment }\end{array}$ & 3.56 & 1.20 & 71.20 & Medium & 7 \\
\hline 6 & The school provides facilities suitable those with special needs & 3.43 & 1.32 & 68.60 & Medium & 8 \\
\hline \multicolumn{2}{|c|}{ Environment } & 3.71 & 0.96 & 74.20 & High & \\
\hline
\end{tabular}

It is noted from Table (8) that the level of the field of environment was high. The means was (3.71) with relative importance of (74.20). The level of items of the field was between medium and high, where the means varied between $(4.03-3.43)$. The item of "the school ensures that its facilities are environmentally friendly" was in the first rank with a means of (4.03) and relative importance of (80.60). The item of "the school provides facilities suitable for those with special needs" was in the last rank with a means of (3.43) and relative importance of (68.60).

This may be attributed to the care for cleanliness as it is one of the essential matters and a priority to provide an appropriate educational environment for the students and the fact that Islam focuses on this issue, which needs to be implanted through educational syllabuses and daily practice in reality. Schools need to organize awareness and educational campaigns on this subject. In addition, it is also related to the hygiene aspect and its importance in the prevention of diseases. This care starts in the family and home and is reinforced by the school within its syllabuses and plan.

With regard to the item that got the least means, namely "the school provides facilities for those with special needs"; this may be attributed to the fact that most of the schools have old buildings that had not been established for this recent purpose. We find it in the schools that are financed by foreign projects due to the material conditions of the Ministry and its affiliate schools, which limit the construction of schools pursuant to the recent international standards and specifications. In addition, there are schools that do care with this category of students (with special needs) since parents place their children in such schools dedicated for this category.

5.2 Results Related to Question 2: What is the Degree of Teachers' Organizational Commitment in Public High Schools in Jordan from the Teachers and Principals' Points of View?

To answer this question, the researchers calculated the means and standard deviations, which are illustrated in Table (9).

Table 9. Means and standard deviations of the fields of the degree of teachers' organizational commitment from the point of view of the principals and teachers in descending order

\begin{tabular}{ccccccc}
\hline No. & Field & Means & $\begin{array}{c}\text { Standard } \\
\text { deviation }\end{array}$ & $\begin{array}{c}\text { Relative } \\
\text { importance }\end{array}$ & Level & order \\
\hline 2 & Responsibility for education & 4.25 & 0.69 & 85.00 & High & 1 \\
3 & The desire to continue at & 4.13 & 0.68 & 82.60 & High & 2 \\
& work & 4.05 & 0.83 & 81.00 & High & 3 \\
1 & Belongingness to work & 0.90 & 75.60 & High & 4 \\
4 & Professional belongingness & 3.78 & 0.68 & 81.00 & High & \\
Organizational commitment & 4.05 & & &
\end{tabular}

It is noted from Table (9) that the fields of the degree of teachers' organizational commitment were high. The means was (4.05) with relative importance of (81.0). The level of fields was high, where the means varied between $(4.25-3.78)$. The field of responsibility for educationwas in the first rank with a means of (4.25) and relative importance of (85.0). The fieldof the desire to continue at work was in the second rank with a means of $(0.68)$ and relative importance of (82.60). The field of belongingness to work was in the third rank with a means of $(0.83)$ and relative importance of (81.0). The field of professional belongingness was in the last rank with a means of (3.78) and relative importance of (75.60).

The researchers analyzed the fields of the degree of teachers' organizational commitment according to its items as follows: 


\section{First: The field of belongingness to work}

The researchers calculated the means and standard deviations of the field of partnership with community as illustrated in Table (10).

Table 10. Means and standard deviations of the items of belongingness to work in a descending order

\begin{tabular}{|c|c|c|c|c|c|c|}
\hline No. & Field & Means & $\begin{array}{l}\text { Standard } \\
\text { deviation }\end{array}$ & $\begin{array}{l}\text { Relative } \\
\text { importance }\end{array}$ & Level & order \\
\hline 4 & The teacher employs his potentials for the service of education & 4.20 & 0.90 & 84.00 & High & 1 \\
\hline 2 & The teacher works with his colleagues with a teamwork spirit & 4.16 & 0.90 & 83.20 & High & 2 \\
\hline 7 & $\begin{array}{l}\text { The teacher participates with the administration and staff in solving the } \\
\text { problems }\end{array}$ & 4.14 & 0.92 & 82.80 & High & 3 \\
\hline 8 & Teacher's values commensurate with work values & 4.08 & 0.95 & 81.60 & High & 4 \\
\hline 1 & The teacher is proud of his profession & 4.06 & 1.08 & 81.20 & High & 5 \\
\hline 6 & The teacher accepts constructive criticism in favor of the work & 4.04 & 0.94 & 80.80 & High & 6 \\
\hline 3 & The teacher considers the school as his second home & 3.97 & 1.08 & 79.40 & High & 7 \\
\hline 5 & The teacher desires to continue at work & 3.75 & 1.24 & 75.00 & High & 8 \\
\hline \multicolumn{2}{|c|}{ Belongingness to work } & 4.05 & 0.83 & 81.00 & High & \\
\hline
\end{tabular}

It is noted from Table (10) that the level of the field of belongingness to work was high. The means was (4.05) with relative importance of (81.0). The level of items of the field was high, where the means varied between (4.20 -3.75). Item (4) "the teacher employs his potentials for the service of education" was in the first rank with a means of (4.20) and relative importance of (84.0). Item (5) "the teacher desires to continue at work" was in the last rank with a means of (3.75) and relative importance of (75.0). It is noted that this field was high in the degree of all its items.

This may be attributed to the fact that teachers have a sense of belongingness to the profession of education and are proud of it too. The teacher considers the school as his second home and is devoted to his work. He feels proud of being a teacher and his values are compatible with the values of the lofty mission of education.

Second: The field of the responsibility for education

The researchers calculated the means and standard deviations of the field of the responsibility for education as illustrated in Table (11).

Table 11. Means and standard deviations of the items of responsibility for education in a descending order

\begin{tabular}{lllllll}
\hline No. & Field & Means & $\begin{array}{l}\text { Standard } \\
\text { deviation }\end{array}$ & $\begin{array}{l}\text { Relative } \\
\text { importance }\end{array}$ & Level & order \\
\hline 5 & The teacher maintains the school properties & 4.38 & 0.77 & 87.60 & High & 1 \\
8 & The teacher wants his school to succeed in all fields & 4.35 & 0.82 & 87.00 & High & 2 \\
1 & The teacher works hard & 4.34 & 0.83 & 86.80 & High & 3 \\
7 & The teacher is keen to maintain school reputation & 4.34 & 0.82 & 86.80 & High & 4 \\
9 & The teacher gives high priority to the accomplishment of & 4.29 & 0.85 & 85.80 & High & 5 \\
& work & 4.27 & 0.85 & 85.40 & High & 6 \\
14 & The teacher dresses well & 4.26 & 0.85 & 85.20 & High & 7 \\
15 & The teacher speaks pleasantly with others & 4.25 & 0.84 & 85.00 & High & 8 \\
4 & The teacher abides by the laws and regulations & 4.24 & 0.86 & 84.80 & High & 9 \\
2 & The teacher attempts to obtain useful information & 4.24 & 0.88 & 84.80 & High & 9 \\
10 & The teacher assists his co-workers & 4.21 & 0.90 & 84.20 & High & 11 \\
6 & The teacher works without control by others & 4.21 & 0.91 & 84.20 & High & 11 \\
11 & The teacher realizes his rights and duties & 4.21 & 0.88 & 84.20 & High & 11 \\
12 & The teacher maintains secrets and privacy of work & 4.18 & 0.86 & 83.60 & High & 14 \\
13 & The teacher acts well in emergent situations & & & & & \\
& The teacher is keen to join training courses to serve his & 4.02 & 1.00 & 80.40 & High & 15 \\
\hline & work & 4.25 & 0.69 & 85.00 & High \\
\hline
\end{tabular}


It is noted from Table (11) that the level of the field of responsibility for education was high. The means was (4.25) with relative importance of (85.0). The level of items of the field was high, where the means varied between (4.38 - 4.02). Item (5) "the teacher maintains the school properties" was in the first rank with a means of (4.38) and relative importance of (87.60). Item (3) "the teacher is keen to attend training courses to serve his work"was in the last rank with a means of (4.02) and relative importance of (80.40). It is noted that this field was high in the degree of all its items.

This may be attributed to the fact that the teacher is always keen to maintain the bright image of the education profession and that he is committed to the laws and morals of this career. He is a breeder for generations and is always keen to develop himself by following-up everything new and joining the training courses. In addition, he continuously cares for professional development and considers this career as a noble mission rather than just a paid work. Education is the mission of prophets through whom the teacher attempts to maintain his position in society by being a role model to others.

Third: The field of the desire to continue at work

The researchers calculated the means and standard deviations of the field of the desire to continue at work as illustrated in Table (12).

Table 12. Means and standard deviations of the items of the desire to continue at work in a descending order

\begin{tabular}{lllllll}
\hline No. & Field & Means & $\begin{array}{l}\text { Standard } \\
\text { deviation }\end{array}$ & $\begin{array}{l}\text { Relative } \\
\text { importance }\end{array}$ & Level & order \\
\hline 2 & The teacher struggles to get promoted & 4.27 & 0.84 & 85.40 & High & 1 \\
6 & The teacher has a good relationship with his colleagues & 4.25 & 0.81 & 85.00 & High & 2 \\
8 & The teacher has an influential personality & 4.16 & 0.83 & 83.20 & High & 3 \\
1 & The teacher cares for professional development at work & 4.13 & 0.88 & 82.60 & High & 4 \\
7 & The teacher deals positively with the concept of time & 4.12 & 0.85 & 82.40 & High & 5 \\
4 & The teacher welcomes any activity that may serve the work & 4.06 & 0.90 & 81.20 & High & 6 \\
3 & The teacher welcomes participation in school committees & 4.05 & 0.92 & 81.00 & High & 7 \\
5 & The teacher looks for another work if there is an opportunity & 4.03 & 1.09 & 80.60 & High & 8 \\
\hline Desire to continue at work & 4.13 & 0.68 & 82.60 & High & \\
\hline
\end{tabular}

It is noted from Table (12) that the level of the field of the desire to continue at work was high. The means was (4.13) with relative importance of (82.60). The level of items of the field was high, where the means varied between $(4.27$ - 4.03). Item (2) "the teacher struggles to get promoted" was in the first rank with a means of (4.27) and relative importance of (85.40). Item (5) "the teacher looks for another work if there is an opportunity"was in the last rank with a means of (4.03) and relative importance of (80.60).

This may be attributed to the fact that the teacher is always keen to maintain the teacher finds the work more comfortable than the other careers and that the salaries were recently improved giving respect to the promotion and professional development received by the teacher during the service. In addition, he finds a sufficient free time, in comparison to other careers, to personally develop himself, although some teachers look for another work if this work is more compensating. Mostly, we find that a good administration is able to maintain its teachers and make them desire to remain and continue at work.

Fourth: The field of professional belongingness

The researchers calculated the means and standard deviations of the field of professional belongingness as illustrated in Table (13).

Table 13. Means and standard deviations of the items of professional belongingness in a descending order

\begin{tabular}{|c|c|c|c|c|c|c|}
\hline No. & Field & Means & $\begin{array}{l}\text { Standard } \\
\text { deviation }\end{array}$ & $\begin{array}{l}\text { Relative } \\
\text { importance }\end{array}$ & Level & order \\
\hline 8 & The teacher is keen to be an active element & 4.02 & 0.96 & 80.40 & High & 1 \\
\hline 3 & The teacher expresses his opinion in a free and democratic way & 3.92 & 1.04 & 78.40 & High & 2 \\
\hline 1 & The teacher feels proud when he speaks about his profession & 3.90 & 1.14 & 78.00 & High & 3 \\
\hline 6 & $\begin{array}{l}\text { The teacher is keen that his private conditions will not affect his } \\
\text { performance }\end{array}$ & 3.87 & 0.99 & 77.40 & High & 4 \\
\hline
\end{tabular}




\begin{tabular}{|c|c|c|c|c|c|c|}
\hline 2 & The teacher considers the school as a wonderful place for work & 3.76 & 1.15 & 75.20 & High & 5 \\
\hline 4 & The teacher participates in the decision-making process & 3.69 & 1.12 & 73.80 & High & 6 \\
\hline 5 & The teacher finds the school atmosphere as comfortable for work & 3.60 & 1.19 & 72.00 & Medium & 7 \\
\hline 7 & The teacher has a sense of security and job stability & 3.45 & 1.26 & 69.00 & Medium & 8 \\
\hline \multicolumn{2}{|c|}{ Professional belongingness } & 3.78 & 0.90 & 75.60 & High & \\
\hline
\end{tabular}

It is noted from Table (13) that the level of the field of professional belongingness was high. The means was (3.78) with relative importance of (75.60). The level of items of the field was between medium and high, where the means varied between $(4.02-3.45)$. Item (8) "the teacher s keen to be an active element" was in the first rank with a means of (4.02) and relative importance of (80.40). Item (7) "the teacher has a sense of security and job stability"was in the last rank with a means of (3.45) and relative importance of (69.0).

This may be attributed to the fact that the career of education has a nature that is different from other careers and has its own privacy. The teacher is committed to his students and society by providing them with the necessary service. He can also express his ideas in a free and democratic way. He feels that he is an active member of society. However, some teachers sometimes have a sense of dissatisfaction and instability. They look for another job maybe due to some problems in some schools, such as the abuse of teachers sometimes and their sense of insecurity and non-protection, which make some of them look for another job. Anyhow, those are few cases and cannot be generalized.

This to some extent agrees with Celep's study (2017), in which results showed that the level of organizational commitment varied between medium and high, and that there was a positive relationship between "conflict management and organizational commitment of teachers and principals". It also agrees with Celep's study (2001), in which results showed that there was a positive relationship between teachers' organizational commitment and their respect for the teaching career and their co-workers.

\section{Recommendations}

In light of the results of the current study, the two researchers recommend the following:

1. To preserve the level of social responsibility among the principals of Public schools and reinforce it by holding forums and courses in this field.

2. To grant rewards and incentives to outstanding principals in the field of social responsibility.

3. To honor the outstanding principals at the Ministry level and disseminate stories of the success of outstanding schools in the field of social responsibility to benefit from them.

4. To enhance outstanding teachers by providing moral support to them by their departments.

5. To adopt the concept of social responsibility by the makers of educational plans and policies at the Ministry of Education and include it within the plan of school syllabuses to inform the students and parents with the importance of social responsibility and the relationship of the school to the community.

\section{References}

Ahmed, N. (2017). School Management and its Relationship to the Motivation of Community towards a Participatory Relationship with Public high schools in Irbid Governorate and Suggestions for Development, unpublished $\mathrm{PhD}$ Thesis, Yarmouk University, Jordan.

Ali, M. (2017). The Serving Leadership among Heads and Supervisors of Academic Departments in Tabuk University and its Relationship to Organizational Commitment among Faculty Members. International Specialized Education Magazine, 6(11), 45-62.

Al-Kayed, J. (1999). Organizational Loyalty in Jordan Official Universities, a Field Study from the point of view of the Faculty Members, unpublished Master Thesis, Yarmouk University, Irbid, Jordan.

Al-Rashidi, M. (2014). A Proposed Insight to activate Organizational Commitment among Teachers in High Schools in Al-Farawaneya. Educational Sciences Magazine, Egypt, 22(4), 603-636.

Al-Sayed, A. A. (2010). Social Responsibility of Asian Universities in the 20th Century. Retrieved from http://www.swmsa.net/news.php?action=showid\&366, 3/11/2017

Al-Subai'ee, N. (2016). The Level of Organizational Commitment among Special Education Supervisors and its Obstacles and Reinforcement Mechanisms in light of some Variables. College of Special Education and Rehabilitation Magazine, Egypt, 3(10), 124-160.

Al-Wazara, A. (2015). The Degree of Organizational Commitment among Faculty Members in Social Sciences 
College in Imam Mohamed Bin Saud Islamic University from their own point of view. Educational Sciences Magazine, 3(4), 12-37.

Attia, M. (2016). Organizational Commitment among Faculty Members of Baha University and its Impact upon their Job Performance Level. Education Magazine, Egypt, 2(171), 66-137.

Awad, Y. (2010). The Guide of Social Responsibility for the Universities, Al-Quds Open University, Amallah, Palestine.

Celeps, C. (2001). Teachers Organizational Commitment in educational organizations. National Fourm Of Teachers Educational Journal, 10(3).

Doaa M (2015). The Measurement of the Level of Organizational Commitment of Social Specialists working in the School Field. Social Service Magazine, Egypt, (53), 185-227.

Mcshance, S., \& Latvon, M. (2005). Organizational behavior, McGraw- Hill: Boston International Edition.

Moore, L., \& Moore, T. (2014). The Effect of ethical climate on the organizational commitment of faculty members. Journal of Academic and Business Ethics, (9), 1-15.

Nevzat, M. (2007). Conflict and Management: A Study Schools of Physical Education and Sportsi. Turkey, 43(2).

Parker, D., Giuffetel, H., \& Flessa, J. (2011). Case Studies Community and climate: success of schools in challenging circumstances. School Community Journal, 1(21), 129-150.

Perston, J (2011). Influencing Community Involment in school: a school community council. McGill Journal of Education, 46(2), 197-212.

Qanadili, J. (2015). Organizational Commitment of Female Teachers in Middle Schools in Mecca. College of Education Magazine, Ain Shams, Egypt, 4(39), 303-374.

Shalash, B. (2017). The Degree of the Application of the Concept of Community School in Public Governorates and its Obstacles from the points of view of Male and Female School Principals, College of Education Magazine, Al-Quds Open University, Palestine.

Vorhis, F., \& Sheldon, S. (2014). Principal's Roles in the development of U.S programs of schools, Family and Community partnerships. International Journal of Education Research, 44(41), 56-90.

\section{Copyrights}

Copyright for this article is retained by the author(s), with first publication rights granted to the journal.

This is an open-access article distributed under the terms and conditions of the Creative Commons Attribution license (http://creativecommons.org/licenses/by/4.0/). 